\title{
A SECOND CHANCE FOR ENTREPRENEURS IN THE REPUBLIC OF MOLDOVA:
} CHALLENGES AND SOLUTIONS

\author{
Alexandra NOVAC', PhD, Research Associate Professor \\ National Institute for Economic Research, Republic of Moldova \\ Elena ACULAI', dr.hab., Research Associate Professor, \\ National Institute for Economic Research, Republic of Moldova, \\ Lidia MAIER ${ }^{3}$, Scientific Researcher, \\ National Institute for Economic Research, Republic of Moldova
}

DOI: https://doi.org/10.36004/nier.es.2021.1-04

JEL Classification: G33, L26, L38, 020, 029,

CZU: 334.72(478)

\section{ABSTRACT}

The relevance of offering a second chance is determined not only by the need to mitigate the consequences of business failure and motivate the entrepreneur to continue his entrepreneurial activity, but also by the impact on the country's economy, as business closure leads to job losses, a worsening of the financial possibilities of the national and local budgets, reduction of competition and other negative trends in the internal market. The importance of these issues has increased significantly in the context of the COVID-19 pandemic, leading to significant deterioration of the Moldovan business environment.

The aim of the paper is to identify the barriers and needs of entrepreneurs, who face financial or other difficulties, are in a state of insolvency, have gone through restructuring/bankruptcy proceedings and would like to benefit from a second chance in Moldova. The research methodology is based on the analysis of legislative acts in the field; statistical data analysis; the results of 16 semi-structured interviews with entrepreneurs on elucidating the factors that favor and hinder the entrepreneurial activity, related to obtaining a second chance in business. The interviews were conducted between April and August 2018.

The research results showed that both internal factors (insufficient financial resources, knowledge of crisis management, mismanagement, insufficient staff qualification, including the entrepreneurial skills / experience of the owners, the lack of people with certain professions) and external (related to insolvency legislation, limited information on the possibilities that can be used in case of failure) are determining for taking a second chance.

Keywords: second chance, entrepreneurship, bankruptcy, business failure

Relevanța oferirii celei de-a doua șanse este determinată nu doar de necesitatea atenuării consecințelor eșecului în afaceri și motivării antreprenorilor să-și continue activitatea antreprenorială ci, de asemenea, de impactul asupra economiei, deoarece închiderea întreprinderilor conduce la reducerea locurilor de muncă, înrăutățirea posibilităților financiare ale bugetelor naționale și locale, reducerea concurenței și la alte tendințe negative pe piața internă. Importanța acestor probleme a crescut semnificativ în contextul pandemiei COVID-19, ducând la deteriorarea semnificativă a mediului de afaceri moldovenesc.

Scopul cercetării este de a identifica barierele și necesitățile antreprenorilor, care se confruntă cu dificultăți financiare sau alte probleme cu caracter nefinanciar, sau se află în stare de insolvabilitate, sau au trecut prin procedurile de restructurare sau faliment şi ar dori să beneficieze în mod rapid de a doua şansă. Metodologia de cercetare se bazează pe analiza actelor legislative în domeniu; analiza datelor statistice; rezultatele a 16 interviuri semi structurate cu antreprenorii privind elucidarea factorilor, care favorizează și împiedică activitatea antreprenorială, legate de obținerea unei a doua șanse în afaceri. Interviurile au fost realizate in perioada aprilie-august 2018.

1 ID ORCID: 0000-0002-4158-4917 e-mail: alecsandra_novac@yahoo.com

2 ID ORCID: 0000-0001-9208-9572 e-mail: eaculai@yandex.com

${ }^{3}$ ID ORCID: 0000-0001-6781-9764 e-mail: heart1961@mail.ru 
Rezultatele cercetării au arătat că atât factorii de ordin intern (insuficienta resurselor financiare, a cunoștințelor în gestionarea crizelor, management defectuos, insuficiența calificării personalului, inclusiv a abilităților/experienței antreprenoriale a proprietarilor, lipsa persoanelor cu anumite profesii, etc), cât și de ordin extern (ce țin de legislația privind insolvabilitatea, informații limitate privind posibilitățile care pot fi utilizate în caz de eșec, etc) în diferite situații sunt determinanți pentru a beneficia de o a doua șansă.

Cuvinte cheie: a doua șansă, antreprenoriat, faliment, eșec în afaceri

Актуальность предоставления второго шанса определяется не только необходимостью смягчения последствий неудач в бизнесе для частных предпринимателей и их мотивацией $\kappa$ продолжению предпринимательской деятельности, но также и влиянием на экономику страны 8 целом, поскольку закрытие предприятий малого и среднего бизнеса приводит крезкому сокращению рабочих мест, существенному ухудшению финансовых возможностей национального и местных бюджетов, неминуемому снижению конкуренции и другим негативным тенденциям на внутреннем рынке. Важность указанных проблем особенно возросла в условиях актуальной пандемии КОВИД-19, которое привело к существенному ухудшению бизнес-среды в Республике Молдова.

Целью исследования является выявление препятствий и потребностей предпринимателей частного бизнеса, которые сталкиваются с определенными финансовыми трудностями или другими нефинансовыми проблемами, либо находятся в состоянии несостоятельности, либо прошли процедуру реструктуризации или банкротства и хотели бы быстро получить второй шанс в Республике Молдова. Методология исследования основана на анализе национальных законодательных актов в данной области; анализе статистических данных; результатах 16 углубленных полустуктурированных интервью с предпринимателями по выявлению факторов, способствующих и препятствующих предпринимательской деятельности, связанных с получением второго шанса в бизнесе. Интервью проводились в период с апреля по август 2018 года.

Результаты исследования показали, что, как внутренние факторы (недостаточные финансовые ресурсы, узкие знания в области антикризисного управления, плохое управление, недостаточная квалификация персонала, в том числе предпринимательские навыки/опыт собственников, отсутствие людей с определенными профессиям, и т. д.), так и внешние факторы (связанные с законодательством о несостоятельности, ограниченная информация о возможностях, которые могут быть использованы предпринимателями в случае неудачи в бизнесе и т. д.) в разных ситуациях могут иметь решающее значение для быстрого получения второго шанса в бизнесе.

Ключевые слова: второй шанс, предпринимательство, банкротство, неудача в бизнесе

\section{INTRODUCTION}

Giving entrepreneurs a second chance in business is a relatively new idea. In Europe, in practical terms, this idea was for the first time proposed for examination about 13 years ago. The importance of this issue is reflected in the EU framework document, which sets out the main priorities for supporting the SMEs sector - the Small Business Act for Europe. Principle II of the Small Business Act states that Member States ensure that "honest entrepreneurs who have faced bankruptcy quickly get a second chance" (Commission Communication 'Think Small First' - A 'Small Business Act' for Europe, 2008). The importance of supporting the second chance in European countries was also reflected in the following document, aimed at the entrepreneurship and SMEs development, approved by the European Commission - the Action Plan "Entrepreneurship 2020" (2013). Measures to create an environment in which entrepreneurs can grow include removing barriers, as „bankruptcy proceedings and giving a second chance to honest entrepreneurs" (European Commission - Entrepreneurship 2020 Action Plan, 2012). In the context of the Association Agreement between the Republic of Moldova and the European Union, the Government of the Republic of Moldova has made similar commitments to comply with the principles and mechanisms for supporting SMEs, provided in the "Small Business Act" for Europe.

It is currently confirmed by statistics and some research that giving a second chance to "honest" entrepreneurs is important not only for the business environment, but also for the society. The need to pay special attention to this issue is conditioned by a number of premises, such as: 
- Bankruptcy in practice is rarely associated with dishonesty. Studies conducted in the EU show that only 1 in 20 bankruptcies involves fraud (5\%). In the EU, 200,000 companies go bankrupt every year, resulting in the loss of 1.7 million jobs. Thus, the problem proves to be important not only for entrepreneurs, but also for the socio-economic development of states, regions;

- Overcoming business failure makes entrepreneurs stronger. In particular, different research confirms the increased efficiency of the entrepreneurs' businesses, who previously had and overcame a negative insolvency experience, compared to other businesses.

Creating a business environment conducive to growth and economic viability is a long-standing goal of policy makers. However, the crucial roles of effective bankruptcy law and, in particular, of a culture that accepts entrepreneurial failure have been given insufficient attention in the process of creating a favorable entrepreneurial environment.

In the Republic of Moldova until recently, the measures regarding the second chance for entrepreneurs and small and medium-sized enterprises, whose businesses have gone bankrupt, have remained outside the legal framework. However, in recent years, a number of concepts and procedures have been clarified in the Insolvency Law, which can potentially contribute to the improvement of the enterprises activities in a crisis situation. Although the legal framework does not in any way prevent bankruptcy business owners from starting new businesses, in reality they face major problems, especially in accessing financial resources and participating in public procurement. They face such a phenomenon as stigma, which inhibits them and prevents them from restarting a new business. For example, in 2015, the Organization for Economic Co-operation and Development, evaluating the implementation of the Small Business Act, had surveyed 310 SMEs in the Republic of Moldova and over $50 \%$ of respondents indicated that it is "very difficult" to start a new business after a previous failure, and that the access to finance represent the main obstacle for them (OECD et al., 2015).

The relevance of this study is due to the fact that knowing the barriers and needs of entrepreneurs who have failed and want to benefit from a second chance aims, first of all, to mitigate the consequences of business failure for the entrepreneurs and motivate them to continue their entrepreneurial activity in the pre-existing business or a new one. Based on the scientific publications and statistical data analysis, as well as in-depth interviews with entrepreneurs, the authors revealed the specifics of the local entrepreneurs' activity, who face financial difficulties or other non-financial problems, are in a state of insolvency, have gone through restructuring or bankruptcy procedures and would like to benefit quickly from a second chance. The generalization of the interviews results allowed to identify and analyze the main constraints and the need of this group of entrepreneurs who would like to benefit from a second chance in the Republic of Moldova.

\section{LITERATURE REVIEW}

In the scientific literature there is not a common definition accepted by the most of scientists, which would reflect the various processes related to business failure, which represent an obstacle both in researching the topic and in solving the practical problems. Usually, several notions are used in scientific papers and policy documents to characterize business failure: business difficulty, inability to pay, insolvency and bankruptcy. Business difficulties (financial and non-financial) are reflected in the worsening of financial and economic indicators, although the company is still able to meet its financial obligations to creditors. The concepts of inability to pay, insolvency and bankruptcy are differently defined, but all means that the debt of a legal person exceeds its assets, respectively, it is not possible to meet its financial obligations (at least in time). At the same time, the inability to pay is not related to court proceedings, and bankruptcy and insolvency are always achieved through a court decision. Also, insolvency can be overcome by restructuring the business, without leading to its bankruptcy.

Researchers focus on various theoretical and practical aspects of offering businesses a second chance. Many of the studies indicate an increasing importance of the need to offer a second chance for honest entrepreneurs. For instance, according to Stam, Audretsch and Meijaard, entrepreneurs who start a second business are more successful and can survive longer than small businesses; they grow faster and employ more workers(Stam et al., 2006). Thus, a failure in entrepreneurial activity should not 
prohibit any future entrepreneurial activity, but rather should be seen as an opportunity for lifelong learning and improvement.

According to some empirical studies, bankruptcy laws that are more friendly to entrepreneurs (in terms of the possibility of obtaining discharge) lead to higher levels of entrepreneurship through a greater number of potential entrepreneurs. A more forgiving bankruptcy law provides partial insurance against the consequences of failure and reduces the risk tolerance threshold for entrepreneurs who are more reluctant to take risks (Armour and Cumming, 2008). At the same time, there is empirical evidence that risk reduction attracts entrepreneurs with higher education, previous experience and, in general, more qualified. And this, in turn, results in the formation of high-performing companies (Eberhart et al., 2012).

There are several barriers that limit the second chance. For example, some researchers note that business success or failure depends on internal or external circumstances. Internal factors can refer to managerial incompetence, overconfidence or excessive risk taking (Hayward et al., 2006). External causes can be related to inadequate economic circumstances, government policies or lack of financial resources (Liao et al., 2008). Also, offering a second chance is limited by lengthy and costly bankruptcy procedures. Faster processes for honest entrepreneurs are therefore important, given that according to research there is a relationship between the length of insolvency procedures and the loss of the company value (Doing Business, f.a.,2019).

Many concepts and approaches argued in scientific research find practical implementation in the European countries policy. In particular, in European policy documents referring to the second chance 10 years ago (including in the SBA for Europe), the notion of bankruptcy was mainly used. In recent years, however, in the European Commission Recommendations and Regulations, the notion of insolvency is more and more common. Moreover, in the text of these documents is recommended to support enterprises in different stages of business failure (the occurrence of problems, but without debts; existence of debts, but without claims from creditors; creditors' claims, but without legal implications; examination of the case in the court). It should be emphasized that attention is paid not only to financial problems, but also to other problems of the enterprises (of a non-financial nature), which can lead to difficulties in the debt recovery.

In the Republic of Moldova, in the scientific literature, there are separately developed the issues of the SME support policy assessment (Aculai et al., f.a.,2018), various aspects of the problems faced by SMEs (Levitskaia et al., 2015), anti-crisis management and the stages of the organization's bankruptcy(Burlacu, f.a., 2009), the assessment of the bankruptcy risk of domestic companies (Bancila \& Mihalachi, f.a., 2012). However, the research gap lies in the fact that the study of the entrepreneurs' challenges, which face financial difficulties or other non-financial problems, are in a state of insolvency, have gone through restructuring or bankruptcy procedures and would like to quickly benefit from a second chance in the Republic of Moldova, is poorly reflected in the national scientific literature. In fact, the study from which this article is based is the first national study in this direction.

In the present study, a second chance for entrepreneurs is examined in a fairly broad context, not limited to the bankrupt companies. So, the whole period is actually subject of the analysis, related to the failure in business - the occurrence of problems (not necessarily financial), but without debts; the existence of debt, but without claims from creditors; creditors' claims, but without judicial implications; examination of the case in court - with the subsequent restructuring or bankruptcy of the enterprise (Figure 1). 


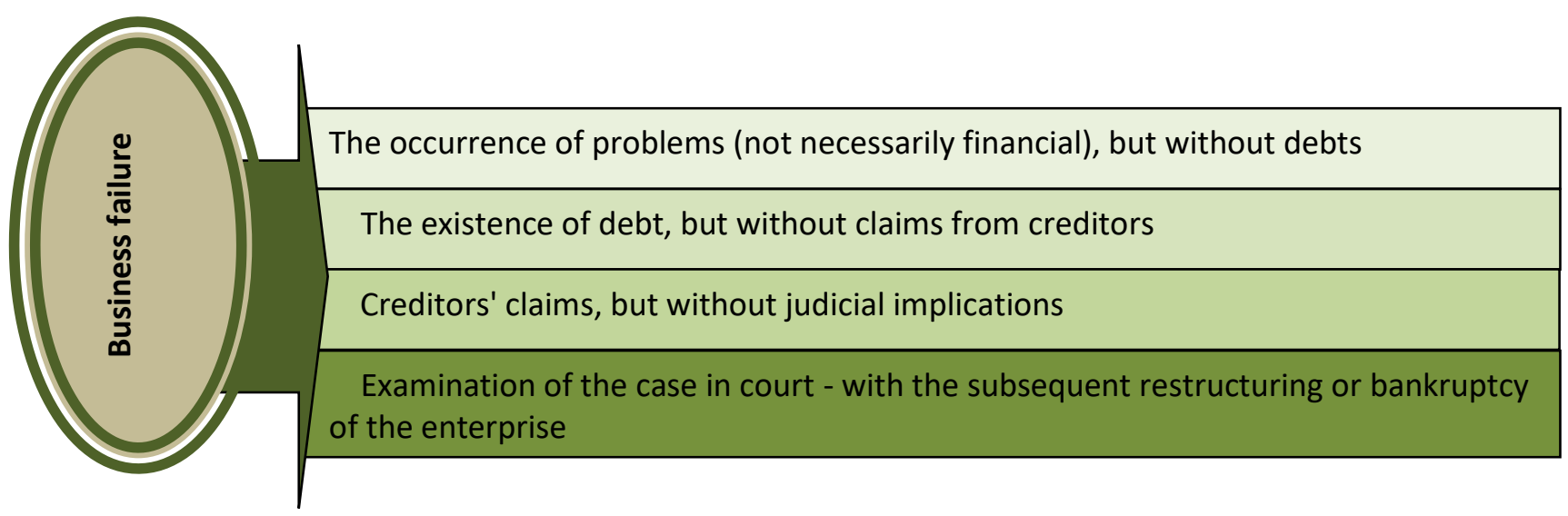

Fig.1 The context of business failure to offer entrepreneurs a second chance Source: elaborated by authors

Thus, this paper contributes to the literature on entrepreneurship in Moldova by empirically investigating the specifics of the activity of local entrepreneurs, who face a business failure and would like to benefit from a second chance, based on interviews with entrepreneurs.

\section{DATA SOURCES AND METHODS}

The data for research in the present article was obtained in the framework of several research projects carried out at the National Institute for Economic Research of Moldova with the active participation of the authors. The following methods were used in this paper: analysis and generalization of the specialized literature, analytical materials, legislative acts and policy documents, which ensure the regulation of entrepreneurship and support for entrepreneurs. The primary data for the entrepreneurs' activity analysis, who have faced financial / non-financial difficulties and intend to restructure their business or set up a new one, was obtained using the in-depth semi-structured interview method, given that the research of this entrepreneurs group in the Republic Moldova is at the initial stage (until now, no studies of these groups of entrepreneurs were carried out in the Republic of Moldova). The purpose of the interviews - to identify the circumstances (factors), which favor and hinder the entrepreneurial activity, related to obtaining a second chance in business. In total 16 interviews were conducted, with the participation of the authors. The interviews were conducted between April and August 2018. The survey was conducted with the following groups of small entrepreneurs (owners / co-owners and top managers), whose business is facing financial difficulties or other non-financial problems, are in a state of insolvency, have gone through restructuring bankruptcy procedures and would like to quickly benefit from a second chance. All respondents hold key positions in the companies, being (co-) owners and/or employees/managers of the company, so that they are well acquainted with the situation in the company, which is discussed in the interviews.

The main notions used in the study - enterprise in financial difficulty, inability to pay, insolvency, bankruptcy- are stated in the local legislation as follows:

- enterprise in financial difficulty - enterprise whose potential of managerial and economic viability is in a decreasing dynamic, but whose holder executes or is able to execute the due obligations;

- inability to pay - the debtor's financial situation characterized by his inability to execute his due pecuniary obligations, including fiscal obligations. Failure to pay is usually presumed if the debtor has ceased to make payments;

- insolvency - the financial situation of the debtor characterized by the inability to honor its payment obligations, ascertained by a court order;

- bankruptcy procedure - the collective and equal insolvency procedure, which is applied to the debtor in order to liquidate his patrimony to cover its debts. 


\section{RESEARCH RESULTS AND DISCUSSIONS}

Insolvency law, main public institutions and implemented projects. The main document, which regulates the insolvency procedure in the Republic of Moldova, is the Insolvency Law, adopted in 2012, most recently amended by the Law No. 141 of 16.07 .2020 . The gravity of the problem is explained by the fact that during the independence period in the country were elaborated 4 laws in this field, respectively, in 1992, 1996, 2001 and 2012, in each of them later were introduced significant changes. In the process of the legislation developing, not only the procedures related to the recovery of corporate debts were concretized and completed, but also the key notions were modified. In particular, instead of the notion of bankruptcy in the law of 2001, the notion of insolvency was introduced, which is considered to be "something more forgiving and easier to bear" for entrepreneurs.

The most recent amendments to the Insolvency Law concern the extrajudicial restructuring of the companies, the streamlining of the financial circuit and the access to finance of economic agents in respect of which the insolvency procedure was initiated, including by regulating the possibility of post-initiation financing, maximizing the recovery rate of creditors' claims.

Analyzing the currently in force Insolvency Law from the second chance point of view, it is worth mentioning that the law provides for two restructuring procedures (Chapter VI, art. 182 226). One is the general procedure and the other is the accelerated restructuring procedure. The accelerated restructuring procedure can be applied to the financially distressed company and aims to protect the company, providing the opportunity to continue the activity, keep jobs and cover debts by implementing a concrete plan.

The main institution, which regulates all aspects of the SME sector development in the Republic of Moldova is the Ministry of Economy and Infrastructure. At the same time, the state policy in the field of enterprises' insolvency and bankruptcy is carried out by the Ministry of Justice.

At the same time, some modest steps are being taken to facilitate the access to second chance for entrepreneurs. Thus, starting with July 2018, the government agency the Organization for SMEs development (ODIMM) started an international project co-financed from European Union funds: "Accepting failure to facilitate the access to second chance for entrepreneurs in the Danube region - Danube Chance 2.0" (within the Transnational Program Danube 2014-2020). The project duration - until 30.06.2021. This is the first project in the Republic of Moldova, focused on entrepreneurs in difficulty, in a state of insolvency or bankruptcy and who would like to start a new business.

Analysis of the importance of the phenomenon based on quantitative data. Based on the available data (of the State Tax Service, the Public Services Agency and the National Bureau of Statistics) was identified the number of the problematic enterprises, which are facing difficulties in recovery debt, or which are already in a state of bankruptcy.

$\checkmark$ The data of the State Tax Service reflects the number of economic agents declared insolvent. Starting with 2013, the number of economic agents declared in a state of insolvency shows a constant growth trend. In particular, a significant increase was registered starting with 2017, when their number exceeded the cumulative number of agents declared insolvent in the period 2013-2016 (by 4.6 times). Over the next 3 years (2017-2019) the number of economic agents declared insolvent continues to increase. Thus, in 2019 the number of economic agents declared in a state of insolvency reached the maximum registered in the analyzed period, constituting 11183 economic agents, increasing by $24.3 \%$ compared to the previous year. The significant increase in the number of economic operators declared insolvent is explained, first of all, by the simplification of the liquidation procedure. 
Table 1.

Number of economic agents declared insolvent, period 2013 - 2019

\begin{tabular}{|c|c|c|c|c|c|c|c|}
\hline Year & Q I & Q II & Q III & Q IV & Total per year & $\begin{array}{l}\text { Average } \\
\text { number of } \\
\text { employees in a } \\
\text { company, } \\
\text { pers. }\end{array}$ & $\begin{array}{l}\text { Average number of } \\
\text { employees in } \\
\text { enterprises } \\
\text { declared insolvent, } \\
\text { pers. }\end{array}$ \\
\hline 2013 & 41 & 64 & 45 & 63 & 213 & 10.1 & 2151 \\
\hline 2014 & 83 & 95 & 72 & 124 & 374 & 9.9 & 3703 \\
\hline 2015 & 112 & 124 & 103 & 120 & 459 & 10 & 4590 \\
\hline 2016 & 161 & 186 & 125 & 201 & 673 & 9.8 & 6595 \\
\hline 2017 & 1783 & 1931 & 2088 & 2161 & 7963 & 9.7 & 77241 \\
\hline 2018 & 1996 & 2126 & 2318 & 2559 & 8999 & 9.6 & 86390 \\
\hline 2019 & 2546 & 2690 & 2866 & 3081 & 11183 & 9.7 & 108475 \\
\hline
\end{tabular}

Source: authors' calculation based on the data of the State Tax Service of the Republic of Moldova and the National Bureau of Statistics

Considering that on average 9.7 employees were working in a company in the Republic of Moldova in 2019, the liquidation of insolvent enterprises only in 2019 may leads to the reduction of 108,475 jobs. Using the data of the National Bureau of Statistics, which shows that the average number of employees in 2019 was 552,113 persons, we identify the share of jobs, which can be liquidated in connection with the closure of enterprises declared insolvent - this is 19.6\%. Given the trend in 2019 and the negative effects of the Covid-19 pandemic crisis, we assume that the reduction in jobs this year may be even more significant.

$\checkmark$ The State Register of Legal Entities and Individual Entrepreneurs keeps records of all enterprises that have been registered and deregistered. The data of the State Register show that during 2015-2016 there was a net growth of enterprises (calculated as the difference between registered and deregistered enterprises), and during 2017-2019 this indicator had a negative value. Moreover, in the last 3 years this negative trend has progressed: in 2017 the monthly reduction in the number of enterprises was -178 units, and in 2019 - 336 units. There are several factors that explain this trend (in particular, the simplification of the business liquidation procedure; a more constructive approach of the potential entrepreneurs on starting their own business), however, the data show the existence of certain problems faced by domestic entrepreneurs.

Table 2

Number of registered and deregistered enterprises from the State Register of legal entities and individual entrepreneurs in the years 2015-2019

\begin{tabular}{|c|c|c|c|c|c|c|c|c|c|c|}
\hline \multirow[b]{2}{*}{ Indicators } & \multicolumn{2}{|c|}{2015} & \multicolumn{2}{|c|}{2016} & \multicolumn{2}{|c|}{2017} & \multicolumn{2}{|c|}{2018} & \multicolumn{2}{|c|}{2019} \\
\hline & Total & $\begin{array}{l}\text { Average } \\
\text { per } \\
\text { month }\end{array}$ & Total & $\begin{array}{l}\text { Average } \\
\text { per } \\
\text { month }\end{array}$ & Total & $\begin{array}{l}\text { Average } \\
\text { per } \\
\text { month }\end{array}$ & Total & $\begin{array}{c}\text { Average } \\
\text { per } \\
\text { month }\end{array}$ & Total & $\begin{array}{c}\text { Average } \\
\text { per } \\
\text { month }\end{array}$ \\
\hline $\begin{array}{l}\text { Registered } \\
\text { enterprises, } \\
\text { un. }\end{array}$ & 5985 & 499 & 5673 & 473 & 6406 & 534 & 5751 & 479 & 6136 & 511 \\
\hline $\begin{array}{l}\text { Deregistered } \\
\text { enterprises, } \\
\text { un. }\end{array}$ & 3905 & 325 & 4055 & 338 & 8540 & 712 & 8895 & 741 & 10166 & 847 \\
\hline Net growth & 2080 & 173 & 1618 & 135 & -2134 & -178 & -3144 & -262 & -4030 & -336 \\
\hline
\end{tabular}

Source: authors' calculation based on the data of the Public Services Agency 
$\checkmark$ Position of the Republic of Moldova in the international ranking Doing business (on indicators, which refer to insolvency). According to the World Bank Doing Business Report, ed.2020, the Republic of Moldova ranked 67th in the "Solving Insolvency" indicator (out of 190 countries included in the ranking), marking a worsening in the ranking with 9 positions (2014-2020) (Doing Business, f.a., 2019).

According to this ranking, the insolvency procedure in the Republic of Moldova lasts on average 2.8 years, and the costs related to the insolvency procedure constitute $15.0 \%$ of the value of the debtor's patrimony, which is above the average in Eastern European and Central Asian countries (respectively, 2.3 years and $13.1 \%$ ) and significantly more than in OECD countries (1.7 years and 9.3\%).

In order to characterize the legislation on insolvency / bankruptcy in the ranking is used the Strength of insolvency framework index, which represents the sum of points assigned to the country for the commencement of proceedings index, management of debtor's assets index, reorganization proceedings index and creditor participation index. The value of the Strength of insolvency framework index for the Republic of Moldova is 12.0 points out of 16 possible, or $75 \%$. At the same time, the insolvency framework does not provide for the possibility of the debtor obtaining credit after the beginning of insolvency proceedings: the country obtaining 0 points on this indicator, which means that the enterprise ceases to exist after the completion of the insolvency process.

The barriers faced by small entrepreneurs, oriented in obtaining a second chance in business. For a deeper investigation of the circumstances (factors), which favor and hinder the entrepreneurial activity, related to obtaining a second chance in business, the interview method was used.

In the process of interviewing, a second chance means if the company: (1) is in financial or nonfinancial difficulty, which poses a threat to paying the debts, or (2) the company is unable to honor its financial obligations (3) the situation created is not related to fraud, then (4) the entrepreneur should have a real opportunity to restart his activities relatively quickly and not too difficult or to create a new business.

The generalization of the interviews results with the entrepreneurs allowed to identify the following barriers, faced by the small entrepreneurs, oriented towards obtaining the second chance in business:

1. Acute insufficiency of financial resources at the enterprise / entrepreneur. The entrepreneurs explained this problem by the following:

- Decrease in sales, conditioned by the change of the goods market conjuncture. For example, the emergence of new competitors in the market, the change in the consumer demand and preferences for the good of the respondents' businesses;

- Increased expenditures, first of all, increased payments for utilities and rent;

- Non-compliance with the financial obligations by customers;

- Deficiencies of the state policy to support entrepreneurship;

- State policy at macro-level (high level of migration, change in exchange rate, corruption, etc.)

2. Long and costly bankruptcy procedures, provided by the insolvency legislation;

3. Limited information about the possibilities an entrepreneur, whose business is in a difficult situation (legal norms, support from institutions, etc.) can use;

4. Insufficient training and experience of persons, who have to solve the problems of creditors and entrepreneurs / enterprises at the stage of insolvency (mediators, consultants, bankruptcy administrators, etc.);

5. Insufficient institutions, interested and with the potential to support entrepreneurs that face financial or other problems in business;

6. The stress of entrepreneurs, who face insolvency or bankruptcy, lack of self-confidence, which is intensified by the distrust from people (both business partners and family members);

7. Staff difficulties, largely caused by:

- Insufficient qualification of employees (workers and specialists) or even lack of people with certain professions and qualifications. Consequently, the employment of people with inadequate qualifications leads to poor quality of work, low discipline, high staff turnover, collective conflicts, etc. 
- Insufficiency of professional qualification and entrepreneurial skills/experience of owners, managers. For example: the owner of the restaurant mentioned that "he started a business he did not know. It was first necessary to study about the activity related to restaurants."

8. Unqualified resolution of general issues related to the enterprise management, such as:

- Contradictions between business owners;

- The main owner and manager had other obligations, working as an employee;

- The goals of business development were not well thought out; management methods and styles were used inefficiently;

- The company was simultaneously involved in several projects, which did not have the necessary financial support;

- The owners of the company were not ready for the risks, or the risks were not taken seriously, or no measures were developed to overcome them;

- Low attention is paid to some management directions, in particular: business planning, including financial planning, price formation was incorrect - prices for products were reduced, no advertising policy, the production control, marketing and supply management were insufficient.

Regarding the success of the new business, after the previous failure in business, the respondents expressed different points of view, including that the new business is in some cases more successful compared to the previous one. One of the respondents clearly mentioned that "the new business differs a lot, in a better sense, from the previous one: it has only one type of activity and a small number of employees. The respondent, being owner and director, has all the advantages in making strategic decisions, while in the previous business there was no mutual understanding between owners and administrators."

At the same time, during the interviews, the entrepreneurs expressed the need for various state support measures to quickly get a second chance. These referred primarily to changes in the legislation and judicial practices related to the bankruptcy procedure, as well as to the financial and institutional support of entrepreneurs to get a second chance. In addition, entrepreneurs paid attention to the general problems of SME development in the Republic of Moldova. In particular, it was proposed:

A. As part of the amendments to the legislation on entrepreneurship and legal practices related to bankruptcy procedures:

- To reduce the duration and complexity of legal procedure related to the closure of the business (in the absence of company debts). This does not require additional financial resources, as it depends largely on the level of bureaucracy.

B. Improving the financial support. Extension of the state support measures, intended for newly established enterprises, including enterprises, which get a second chance. It is reasonable to implement these measures in the framework of the SME support programs. In particular:

- to extend the state support under special/target programs for all Moldovan SME, including those operating in Chisinau (given that $64 \%$ of domestic economic agents operate in the capital). Currently, support under special programs is intended primarily for businesses from the rural areas.

- As possible state support measures for SME in the crisis situations, was proposed: 1) to reduce the rent payment (if the owner of the area is the state) or to compensate a part of the rent payment, which is very high at the moment; 2) postponement of the tax payment for the equipment and tools purchase necessary for the business development. For example, the respondent ordered a computer program abroad to develop mail delivery models. The cost of the program was $\$ 9,000$, the tax was $\$$ 2,000. The respondent refused to pay such a fee and had to go to Moscow alone to bring the program, significantly reducing the purchasing cost.

C. Within the institutional support. Any opportunities for institutional support of the second chance were enthusiastically supported by respondents, considering that improving the institutions activity is the most possible support form for entrepreneurs. In particular, it was proposed:

- Development of institutions that provide services to entrepreneurs:

$\circ$ at the stage of identifying new complicated problems in the business - by providing assistance in the restructuring process, in order to keep the company and the jobs. According to the respondents 
"these services must be provided by public institutions, free of charge, given the state's interest in protecting jobs and paying taxes";

○ willing to set up a new business or restart the previous activity after a forced cessation of activity or bankruptcy.

- Extending the process of informing entrepreneurs how to overcome the business problems.

- Assistance of professional psychologists in organizing counseling, to reduce the impact of stigmatization of the "bankrupt". Organizing the training of entrepreneurs in the field of risk management, crisis management, staff development; delegation of responsibilities; providing psychological support. The respondents mention that "it must be free and include rural areas".

- Development of methodological instructions for entrepreneurs on early prevention of crisis situations, insolvency management, bankruptcy.

- Dissemination in society of information about the existence of the right to failure in any activity.

The generalization of the interviews results with the entrepreneurs and the legislation analysis allowed to identify a range of directions to support the second chance, the main ones being the following:

- Improving the legislation and the control over its implementation; introducing changes in the policy documents. In particular, it is proposed: (a) to include in the aim of the Insolvency Law, in line with the interests of creditors, also - where possible, giving the debtor-entrepreneur the chance to recover it business; (b) to add in the Law on Small and Medium-sized Enterprises, in particular, to the list of the target groups supporting SMEs, the group of entrepreneurs, who may benefit from the second chance.

- Facilitating the access to funding sources. In particular, during and after the financial crisis, the following forms of financial support for entrepreneurs are important: (i) reducing the debt burden for entrepreneurs, who have got a second chance (lower rates for unpaid debts); (ii) the possibility to obtain a loan after the initiation of the insolvency process, in particular, within the special programs; (iii) ensuring the access to state contracts for "honest" bankrupt entrepreneurs; (iv) providing facilities to entrepreneurs for payments, offered to consultations of lawyers, financiers, accountants and other insolvency specialists, whose services are usually quite expensive.

- Improving the training of entrepreneurs; providing advisory and information services. In particular: (1) training of entrepreneurs regarding the activity in difficult conditions, in particular, training courses on risk management, crisis management; personnel management; financial management; (2) training and advisory assistance of business specialists in overcoming crisis issues; (3) organizing mentoring and coaching activities to help those who want to get a second chance; (4) informing entrepreneurs from the SME sector about the possibility of using the restructuring procedure to overcome a business crisis situation; (5) developing and maintaining the website, which places the information necessary for the second chance.

- Changing the activity of institutions, aimed at giving SMEs a second chance. In order to support SMEs in overcoming financial insolvency, it is appropriate for the state to initiate or create specialized support institutions, or to assign new functions to existing public institutions. Certain functions of granting a second chance to entrepreneurs in the Republic of Moldova are performed by persons with liberal professions (mediators, bankruptcy administrators) and their professional associations, whose activities are regulated by the Ministry of Justice. It is very important to provide assistance to companies in identifying difficulties at the initial stage of their emergence. In particular, as early warning systems could be the tax authorities, commercial banks, credit bureaus.

- Changing the attitude in society about entrepreneurs, who have suffered a failure in business, in order to improve the public image through education and media. In this context, it is relevant to disseminate information in society: (a) about the right to fail in any activity, especially in the field of business, characterized by a high degree of risk; (b) the success stories of entrepreneurs who have overcome crisis situations; (c) in a broader context - about improving the image of entrepreneurs. 


\section{CONCLUSIONS}

Giving entrepreneurs a second chance is not limited to companies that have gone bankrupt, but is examined in a broader context in the politics of European countries. In particular, these are companies that are in financial difficulty or are facing non-financial difficulties; who have faced insolvency, have gone through restructuring or bankruptcy procedures.

In order to develop a policy to support the second chance in business, it is rational to identify the barriers that small entrepreneurs face, which can lead the company to bankruptcy. The constraints of the local entrepreneurs, who have suffered a failure in business and would like to quickly benefit from a second chance in the Republic of Moldova are characterized by the following: (a) acute shortage of financial resources in the enterprise; (b) long and costly bankruptcy procedures; (c) limited information on the possibilities an entrepreneur whose business is in a difficult situation can use; (d) inadequate training and experience of specialists who have to deal with business difficulties (mediators, consultants, bankruptcy administrators, etc.); (e) the insufficient level of training of entrepreneurs in the field of business, in which insufficient attention is paid to issues related to the risk management; the crisis management, the human resources management, the financial management, etc.); (f) insufficient institutions, interested in supporting entrepreneurs, facing financial or other business problems; (g) stress of entrepreneurs, facing insolvency or bankruptcy procedures, lack of self-confidence, which is intensified by the distrust of people.

In order to give entrepreneurs a second chance, it is relevant to use a wide range of support directions, the main ones being the following: (1) improving the legislation and controlling its implementation; (2) facilitating the access to funding sources; (3) improving the entrepreneurial training of persons involved in business and improving the professional qualification of other participants of the insolvency process; (4) changing the attitude in society towards entrepreneurs, who have suffered a failure in business, in order to improve the public image through education and media.

\section{REFERENCES}

1. Aculai, E., Stratan, A., \& Novac, A. (f.a.). SME support policy in the Republic of Moldova and assessment of its impact on business development. NIER. https://economysociology.ince.md/sme-support-policy-in-the-republic-of-moldova-and-assessment-of-itsimpact-on-business-development-2/

2. Armour, J., \& Cumming, D. (2008). Bankruptcy Law and Entrepreneurship. American Law and Economics Review, 10(2), 303-350.

3. Băncilă, N., \& Mihalachi, R. (f.a.). Predicţia riscului de faliment al firmei. Economy and Sociology, 3, 92-97.

4. Burlacu, N. (f.a.). Managementul anticriză: Stadiile falimentului organizației. Analele Universităţii Libere Internaţionale din Moldova., 8, 47-56.

5. Doing Business. (f.a.). [Text/HTML]. World Bank. Preluat în 28 aprilie 2021, din https://www.doingbusiness.org/en/doingbusiness

6. Eberhart, R., Eesley, C., \& Eisenhardt, K. (2012). Failure is an option: Failure barriers and new firm performance. https://www.yumpu.com/en/document/read/11445866/failure-is-anoption-stanford-university

7. Hayward, M. L. A., Shepherd, D. A., \& Griffin, D. (2006). A Hubris Theory of Entrepreneurship. Management Science, 52(2), 160-172. https://doi.org/10.1287/mnsc.1050.0483

8. Levitskaia, A., Ghenova, S., \& Curaxina, S. (2015). State policy of innovation - oriented SMEs development: In case of the Republic of Moldova. http://irek.ase.md:80/xmlui/handle/1234567890/1140

9. Liao, J. (Jon), Welsch, H., \& Moutray, C. (2008). Start-Up REsources and Entrepreneurial Discontinuance: The Case of Nascent Entrepreneurs. Journal of Small Business Strategy, 19(2), $1-16$.

10. OECD, European Training Foundation, European Union, \& European Bank for Reconstruction and Development. (2015). SME Policy Index: Eastern Partner Countries 2016: Assessing the Implementation of the Small Business Act for Europe. OECD. https://doi.org/10.1787/9789264246249-en 
11. Stam, E., Audretsch, D., \& Meijaard, J. (2006). Renascent Entrepreneurship. ERIM Report Series Research in Management Erasmus Research Institute of Management, Article ERS-2006-017ORG. https://repub.eur.nl/pub/7640/

Note: The article is part of the research, funded by the projects:

- $\quad$ "Harmonization of SME development policy in the Republic of Moldova with the principles of the "Small Business Act" for Europe" (2015-2018), stage 2018 "Improving the policy of SME support in the Republic of Moldova: improving opportunities for entrepreneurs, who have gone bankrupt and can quickly get a second chance" (№ 15.817.06.05A)

- "Multidimensional evaluation and development of the entrepreneurial ecosystem at national and regional level in order to boost the SME sector in the Republic of Moldova" (№20.80009.0807.38), 2020-2023

\section{ARTICLE HISTORY}

Received 05 December 2020

Accepted 06 May 2021 